\title{
Physical and chemical changes in whey protein concentrate stored at elevated temperature and humidity
}

\author{
Michael H. Tunick, ${ }^{* 1}$ Audrey Thomas-Gahring, ${ }^{*}$ Diane L. Van Hekken, ${ }^{*}$ Susan K. landola, ${ }^{*}$ Mukti Singh, $\dagger$ \\ Phoebe X. Qi, ${ }^{*}$ Dike O. Ukuku,ł Sudarsan Mukhopadhyay,§ Charles I. Onwulata, ${ }^{*}$ and Peggy M. Tomasula* \\ *Dairy and Functional Foods Research Unit, Eastern Regional Research Center, Agricultural Research Service, USDA, 600 E. Mermaid Lane, \\ Wyndmoor, PA 19038 \\ †Functional Foods Research Unit, National Center for Agricultural Utilization Research, Agricultural Research Service, USDA, \\ 1815 N. University St., Peoria, IL 61604 \\ ‡Food Safety and Intervention Technologies Research Unit, Eastern Regional Research Center, and \\ §Residue Chemistry and Predictive Microbiology Research Unit, Eastern Regional Research Center, Agricultural Research Service, \\ USDA, 600 E. Mermaid Lane, Wyndmoor, PA 19038
}

\section{ABSTRACT}

In a case study, we monitored the physical properties of 2 batches of whey protein concentrate (WPC) under adverse storage conditions to provide information on shelf life in hot, humid areas. Whey protein concentrates with $34.9 \mathrm{~g}$ of protein/100 g (WPC34) and $76.8 \mathrm{~g}$ of protein/100 g (WPC80) were stored for up to 18 mo under ambient conditions and at elevated temperature and relative humidity. The samples became yellower with storage; those stored at $35^{\circ} \mathrm{C}$ were removed from the study by 12 mo because of their unsatisfactory appearance. Decreases in lysine and increases in water activity, volatile compound formation, and powder caking values were observed in many specimens. Levels of aerobic mesophilic bacteria, coliforms, yeast, and mold were $<3.85 \log _{10} \mathrm{cfu} / \mathrm{g}$ in all samples. Relative humidity was not a factor in most samples. When stored in sealed bags, these samples of WPC34 and WPC80 had a shelf life of $9 \mathrm{mo}$ at $35^{\circ} \mathrm{C}$ but at least 18 mo at lower temperatures, which should extend the market for these products.

Key words: whey protein concentrate, color, powder flow, volatiles

\section{INTRODUCTION}

The liquid whey generated during cheesemaking may be ultrafiltered and dried to produce whey protein concentrate (WPC) powder with a recommended shelf life of 9 to 12 mo (Sithole et al., 2005; Javidipour and Qian, 2008), which may be extended to 24 mo under refrigeration. The United States exported over 115,000

Received August 14, 2015.

Accepted November 12, 2015.

${ }^{1}$ Corresponding author: michael.tunick@ars.usda.gov t of WPC in 2014, with China, Indonesia, and Malaysia being major importing countries (Lagrange et al., 2015). A study by the US Agency for International Development and Tufts University recommended that emergency aid foods include WPC to prevent stunted growth in children (Webb et al., 2011), which should further expand the market. In all likelihood, the nutritional benefits provided by WPC will continue to increase the global demand for whey proteins (Lagrange et al., 2015). However, the bags of WPC sent overseas are usually stored without refrigeration, exposing the product to elevated temperature and humidity. The shelf life of WPC under these conditions must be known to prevent the product from being rejected.

Maillard reactions and color changes have been observed in shelf-life studies of sweet whey powder (Sithole et al., 2005), as have lipid oxidation (Wright et al., 2009), volatile compound formation (Lee et al., 1996), and reduction of lysine (Li-Chan, 1983). The WPC is typically transferred from the original bags to lidded bins (Wright et al., 2009), sealed bottles (Lee et al., 1996; Sithole et al., 2005), or polyethylene bags (LiChan, 1983) for laboratory evaluation of storage properties. These studies do not reflect the actual storage conditions of WPC bags, however, because water vapor permeability characteristics would differ. Shelf-life studies of full-size bags of WPC have not been conducted, primarily because the facilities available for such studies are limited. Therefore, walk-in environmental chambers were obtained for storing bags of WPC at temperatures of 25,30 , and $35^{\circ} \mathrm{C}$ at relative humidity $(\mathbf{R H})$ levels of 70 and $90 \%$. Another chamber at ambient temperature and RH (uncontrolled) was used. Because WPC bags may be subjected to rough handling, half of the samples had been sealed in standard (ST) bags and half in high-performance (HP) bags to determine if packaging affected the results. The physical properties and microbial quality of WPC containing 34 and $80 \%$ 
protein (WPC34 and WPC80, respectively) were then determined over an 18-mo period.

\section{MATERIALS AND METHODS}

\section{Sample Bags}

A dairy processor supplied 78 bags of WPC34 (34.9 $\mathrm{g}$ of protein $/ 100 \mathrm{~g}$ ) and $78 \mathrm{bags}$ of WPC80 (76.8 $\mathrm{g}$ of protein/100 g) derived from Mozzarella cheese manufacture. Half of the samples had been packaged in HP bags (with a plastic liner $0.16 \mathrm{~mm}$ thick) and half in ST bags (liner was $0.10 \mathrm{~mm}$ thick). All bags contained 3 layers of Kraft paper glued across the top, with the low-density polyethylene liner in contact with the WPC and heat sealed near the top. The bags were divided evenly and placed inside environmental chambers. One WPC34 bag and 1 WPC80 bag were removed from each chamber and opened at each analysis time $(0,3,6,9,12$, and $18 \mathrm{mo}$ ). Samples were transferred by plastic scoop or metal spoon into Whirl-Pak containers (Nasco, Ft. Atkinson, WI) for testing, which took place within a week. Some bags were not analyzed at 3 mo and others not at 6 mo because of personnel limitations. Unopened bags were always used and opened bags were discarded after sampling.

\section{Environmental Chambers}

The chambers (Bally Refrigerated Boxes, Bally, PA) were $1.57 \mathrm{~m}$ wide, $1.87 \mathrm{~m}$ deep, and $1.83 \mathrm{~m}$ high. Heating was supplied by model HD3D heaters (Chromolox, Pittsburgh, PA) and humidification by model MP-5 ultrasonic humidifiers (Humidifirst, Boynton Beach, FL). The conditions in the 7 chambers were ambient (about $21^{\circ} \mathrm{C}, 45-65 \% \mathrm{RH}$ ), $25^{\circ} \mathrm{C} / 70 \% \mathrm{RH}, 25^{\circ} \mathrm{C} / 90 \%$ $\mathrm{RH}, 30^{\circ} \mathrm{C} / 70 \% \mathrm{RH}, 30^{\circ} \mathrm{C} / 90 \% \mathrm{RH}, 35^{\circ} \mathrm{C} / 70 \% \mathrm{RH}$, and $35^{\circ} \mathrm{C} / 90 \% \mathrm{RH}$.

\section{pH and Water Activity}

The $\mathrm{pH}$ was determined in triplicate by mixing 28 $\mathrm{mL}$ of deionized water with $12 \mathrm{~g}$ of whey protein and stirring for $1 \mathrm{~h}$ before measuring. Water activity $\left(\mathbf{a}_{\mathrm{w}}\right)$ of 1-g samples was measured in triplicate by AquaLab 4TE water activity meter (Decagon Devices, Pullman, WA).

\section{Color}

Color was measured by ColorQuest XE spectrophotometer (Hunter Associates Laboratory, Reston, VA) in the RSIN mode using a 20-mL cuvette and a 19-mm aperture. Three readings were taken for each sample and lightness $\left(\mathbf{L}^{*}\right)$, red-green color $\left(\mathbf{a}^{*}\right)$, and yellowblue color $\left(\mathbf{b}^{*}\right)$ were recorded.

\section{Lysine}

A GC-EZ Faast Kit (Phenomenex, Torrance, CA) was used to determine lysine content. Samples were treated with proprietary wash, derivatization, and purification solutions in a tube at room temperature. The derivatized lysine was analyzed by GC with flameionization detection.

\section{Volatile Compounds}

The procedure for analyzing volatile compounds, based on Tunick et al. (2013), utilized solid-phase microextraction (SPME). After warming a sample to $40^{\circ} \mathrm{C}$ for $25 \mathrm{~min}$, a divinylbenzene (DVB)/Carboxen/ polydimethylsiloxane (PDMS) Stableflex SPME fiber (Supelco, Bellefonte, PA) was exposed to the headspace above the sample in a closed vial for $30 \mathrm{~min}$. The fiber was injected into a Varian gas chromatograph (model 3380, Varian, Walnut Creek, CA) equipped with a DB-5 column (30 m, $0.25 \mathrm{~mm}$ i.d., $0.25 \mu \mathrm{m}$ film thickness; Restek US, Bellefonte, PA). The volatiles were desorbed for $5 \mathrm{~min}$ at $250^{\circ} \mathrm{C}$ and the $\mathrm{GC}$ oven was heated from 40 to $225^{\circ} \mathrm{C}$ at $10^{\circ} \mathrm{C} / \mathrm{min}$ and held for $3 \mathrm{~min}$. The detector was a Varian Saturn 200 mass spectrometer and the internal standard was 2-methyl-3-heptanone (Sigma Aldrich, St. Louis, MO). Volatile compounds were identified by the National Institute of Standards and Technology (NIST) library in the instrument's software and by comparison with authentic standards (Sigma Aldrich). Samples were analyzed in triplicate.

\section{Fatty Acids}

Lipids were extracted with a Foss 2050 Soxtec Automatic Extractor (Foss North America, Eden Prairie, $\mathrm{MN}$ ) using the procedure for powdered products described by Richardson (2001). Extracted lipids were stored at $-20^{\circ} \mathrm{C}$ under nitrogen.

A KOH-catalyzed methanolysis method for preparation of FAME was followed (Ichihara et al., 1996). Samples were analyzed on a Varian 3400 CX gas chromatograph with a Supelco 2380 capillary column $(30 \mathrm{~m} \times 0.25 \mathrm{~mm} \times 0.20 \mu \mathrm{m}$ film thickness $)$, a flameionization detector, and $\mathrm{He}$ as carrier gas. The injector and detector temperatures were $240^{\circ} \mathrm{C}$ and $250^{\circ} \mathrm{C}$, respectively. The column temperature was held at $50^{\circ} \mathrm{C}$ for $3 \mathrm{~min}$, raised to $150^{\circ} \mathrm{C}$ at $10^{\circ} \mathrm{C} / \mathrm{min}$, held $1 \mathrm{~min}$, raised to $222^{\circ} \mathrm{C}$ at $3^{\circ} \mathrm{C} / \mathrm{min}$, held $1 \mathrm{~min}$, and finally raised to $240^{\circ} \mathrm{C}$ at $10^{\circ} \mathrm{C} / \mathrm{min}$ and held $5 \mathrm{~min}$. The area peaks were identified by comparison of the sample peak 
retention times to those of known FAME reference compound mixtures from Supelco and $\mathrm{Nu}$-Chek Prep (Elysian, MN). Samples were analyzed in triplicate and results were reported as peak area percentages.

\section{Flow Tests}

Flow function and wall friction tests were performed using a PFT Powder Flow Tester (Brookfield Engineering Laboratories, Middleboro, MA) using the procedure of Crowley et al. (2014). A 152.4-mm stainless steel trough was filled with sample and leveled using the plow side of the shaping blade. Maximum bulk density, critical rathole density, critical rathole diameter, critical arching density, and critical arching diameter were reported. All samples were analyzed in duplicate.

\section{Powder Caking and Relaxation}

Caking and relaxation tests were conducted by TAXT2 texture analyzer (Texture Technologies Corp., Scarsdale, NY) using a procedure similar to that described by Listiohadi et al. (2005) for dairy powders. Instead of paper cylinders, the instrument was equipped with a TA-402 Low Force Compaction Rig 1/2" model (Texture Technologies Corp.) with openings approximately $0.025 \mathrm{~mm}$ wider than the probe. Approximately $0.50 \mathrm{~g}$ of sample was placed into each opening and a force of 4,500 g was applied for $4 \mathrm{~s}$ at a test speed of 0.5 $\mathrm{mm} / \mathrm{s}$ once the trigger force of $30 \mathrm{~g}$ had been reached. The distance packed under the 4,500-g force was designated as the degree of caking.

Using the previously compacted $0.50-\mathrm{g}$ specimen from the caking test, the powder was compacted $1.5 \mathrm{~mm}$ and held for $60 \mathrm{~s}$ and the peak force and the decrease in force at $45 \mathrm{~s}$ were recorded. The percentage change in force indicated the loss of strength in the powder over time. Five replicates of the caking and relaxation tests were analyzed.

\section{Solubility}

A method developed in our laboratory for analyzing whey protein was used (Qi et al., 2015). A 10\% (wt/wt) suspension was made by combining $0.10 \mathrm{~g}$ of sample with $9.0 \mathrm{~mL}$ of MilliQ double-distilled deionized water (Millipore Corp., Billerica, MA). The mixture was stirred vigorously for $2 \mathrm{~h}$ and centrifuged (Sorvall Legend X1R, Thermo Fisher Scientific Inc., Santa Clara, $\mathrm{CA}$ ) for $30 \mathrm{~min}$ at $24,000 \times g$ at room temperature. The supernatant was removed and filtered through a $0.45-$ $\mu \mathrm{m}$ syringe filter (Millex-HV PVDF, Millipore Corp.). The UV-Vis absorption spectrum (Varian Spectropho- tometer Bio100 UV-visible, Agilent Technologies, Santa Clara, CA) was recorded against MilliQ water as the reference. The absorption (A) at $280 \mathrm{~nm}$ was corrected for light scattering $\left(\mathrm{A}_{330} \gg 0.0\right)$ using the following equation (Grimsley and Pace, 2004):

$$
\mathrm{A}_{280(\text { corrected })}=\mathrm{A}_{280}-1.929 \times \mathrm{A}_{330} ;
$$

$\mathrm{C}$, the concentration of soluble WPC, was then estimated using Beer's Law:

$$
\mathrm{C}=\mathrm{A}_{280 \text { (corrected) })} /\left(\varepsilon_{280} \cdot \mathrm{L}\right),
$$

where $\varepsilon_{280}$ is the extinction coefficient for whey protein, determined to be $1.046 \mathrm{~L} \cdot \mathrm{g}^{-1} \cdot \mathrm{cm}^{-1}$ (Mahmoudi et al., 2007 ), and $\mathrm{L}$ is the $1.0-\mathrm{cm}$ path length of the cuvette. The percentage total soluble protein was determined by dividing the soluble protein concentration by the total initial concentration of the suspension.

\section{Microbiology}

Bacteria, yeast, mold, and coliform populations were plated on agar (Difco Laboratories Inc., Detroit, MI) using the method of Ukuku et al. (2014). Mesophilic aerobic bacteria were plated on tryptic soy agar and incubated at $36^{\circ} \mathrm{C}$ for $24 \mathrm{~h}$; spoilage yeast and molds were plated on dichloran rose bengal chloramphenicol agar and incubated at $23^{\circ} \mathrm{C}$ for $5 \mathrm{~d}$; and coliforms were plated on violet red bile agar and incubated at $36^{\circ} \mathrm{C}$ for $24 \mathrm{~h}$. Microbial enumeration was carried out according to Hitchins et al. (1992).

\section{Statistics}

Results from the various analyses were analyzed using sample and bag types, and storage time, temperature, and RH as the main effects (SAS version 9.2 for Windows; SAS Institute Inc., Cary, NC). Significant differences $(P<0.05)$ among means were compared using the Bonferroni correction within the PROC MIXED program.

\section{RESULTS AND DISCUSSION}

\section{Composition}

The compositional data of the powders according to assays performed by the manufacturer were within legal definitions and confirmed by our analyses. The $\mathrm{pH}$ of the WPC34 was initially 6.37 to 6.47 and was 6.30 to 6.40 at $18 \mathrm{mo}$, a nonsignificant difference. The $\mathrm{pH}$ of the WPC 80 was 6.23 to 6.33 at 0 mo and decreased 
significantly $(P<0.05)$ to 5.80 to 6.00 by 18 mo. Relative humidity and bag type did not affect the results. The WPC80 contained more than twice as much fat as the WPC34, and free fatty acid formation presumably contributed to its $\mathrm{pH}$ decrease.

\section{Color}

Initially, L* values were 89.2 for WPC34 and 87.4 for WPC80 (where 0 is black and 100 is diffuse white). After $18 \mathrm{mo}$, the $\mathrm{L}^{*}$ values decreased to 86.9 to 88.5 for WPC34 and 85.3 to 87.3 for WPC80. These differences were not significant. All samples became yellower with storage, as evidenced by increases in the $\mathrm{b}^{*}$ values (negative numbers are blue and positive numbers are yellow). The yellow appearance was especially noticeable in samples stored at $35^{\circ} \mathrm{C}$ (Figures 1 and 2); Figure 3 shows some of the $\mathrm{b}^{*}$ results. Initially, the $\mathrm{b}^{*}$ values were 10.8 and 8.9 for WPC34 and WPC80, respectively. The results at a particular storage temperature were not significantly affected by bag type or RH. The increases in $\mathrm{b}^{*}$ in WPC34 stored at ambient temperature and $25^{\circ} \mathrm{C}$ were not significant, but the increases were significant $(P<0.05)$ for WPC34 and WPC80 stored at 30 and $35^{\circ} \mathrm{C}$. The largest changes were observed at $35^{\circ} \mathrm{C}$, where all of the $\mathrm{b}^{*}$ values were 17.1 to 19.1 after 9 mo and 19.9 to 25.0 after 12 mo. No sample held at a lower temperature exceeded $\mathrm{a} \mathrm{b}^{*}$ value of 16.8 at any time during the $18 \mathrm{mo}$. The bags held at $35^{\circ} \mathrm{C}$ were removed from the study after 12 mo because of the probability they would be rejected by the end user. The shelf life of WPC bags stored at this temperature is therefore 9 mo at the most.

Starting at $12 \mathrm{mo}$, large brown chunks were observed at the tops of the bags stored at $90 \% \mathrm{RH}$ and $35^{\circ} \mathrm{C}$, and smaller chips were seen at the top of the WPC34 bags stored at $90 \% \mathrm{RH}$ and 25 and $30^{\circ} \mathrm{C}$ (Figure 4). No chips were observed in the WPC80 samples, which contained much less lactose than the WPC34, or in the bags stored at lower RH. The chips and chunks may have been caused by crystallization of the lactose by moisture, which would increase browning reactions with lysine (Li-Chan, 1983; Sithole et al., 2005). Moreover, hydrolysis of a disaccharide (lactose) to monosaccharides (glucose and galactose) increases the number of reactive groups available for nonenzymatic browning reactions (Buera et al., 1990). Some starter cultures used in cheesemaking ferment the glucose portion of the lactose molecule, which would enhance hydrolysis (Dattatreya et al., 2010). The moisture that led to browning would have come from a combination of 3 sources: loss of moisture from the powder at elevated temperatures, moisture in the air inside the top of the bag, and moisture-laden air seeping into the bags (par- ticularly at $90 \% \mathrm{RH})$. The thicker HP bags, which were tested because of their presumed ability to withstand violent handling, also exhibited brown chip and chunk formation. The recommended storage conditions for WPC are $<25^{\circ} \mathrm{C}$ and $<65 \% \mathrm{RH}$, with 3 - to 4-ply multiwall Kraft paper bags and a 3- to 4-mil (0.076-0.102 $\mathrm{mm}$ ) thickness low-density polyethylene bag liner (US Dairy Export Council, 2014). The ST bags met the packaging conditions and the HP bags exceeded the conditions, but the temperature and RH (except for the ambient samples) were outside the ideal range. The USDA requires that the maximum water vapor transmission of the liners that they purchase for food assistance programs should be $0.45 \mathrm{~g} / 100 \mathrm{in}^{2}\left(645 \mathrm{~cm}^{2}\right)$ in $24 \mathrm{~h}$ at $37.8^{\circ} \mathrm{C}$ and 90 to $95 \% \mathrm{RH}$ (USDA, 2006). Over $12 \mathrm{mo}, 164 \mathrm{~g}$ of water could conceivably be absorbed in a square section $25.4 \mathrm{~cm}$ on a side. The HP bags did not prevent browning.

\section{Lysine}

Whey protein is rich in branched-chain AA, which help build muscles; in arginine and lysine, which stimulate growth hormone; and in cysteine, which prevents protein breakdown when the immune system is challenged during illness (Webb et al., 2011). Nine to $10 \%$ of the AA residues in whey proteins are lysine, making whey a good dietary source of this essential AA. The lysine in the WPC80 was greater than that of the WPC34 throughout the study because of the disparity in protein contents. The levels in WPC vary with the type of processing (Delaney, 1976) and are reduced as Maillard reactions occur. The lysine content in the WPC34 bags was initially 4.3 to $4.9 \%$ and decreased significantly to 0.9 to $1.5 \%$ during $12 \mathrm{mo}$ of storage. The WPC80 originally contained 5.4 to $5.5 \%$ lysine and decreased significantly to 2.6 to $4.2 \%$ at 12 mo. Lysine content was not significantly affected by $\mathrm{RH}$ or bag type. Brown pigment formation and lysine loss in whey powders are at a maximum at elevated temperatures and when $\mathrm{a}_{\mathrm{w}}=0.44$ (Labuza and Saltmarch, 1982).

\section{Water Activity}

Water activity was monitored to determine the potential for growth of microorganisms. The $\mathrm{a}_{\mathrm{w}}$ of WPC34 stored at ambient conditions was 0.28 through the first 12 mo and was 0.31 after 18 mo. Other WPC34 samples stored for 12 mo exhibited $\mathrm{a}_{\mathrm{w}}$ values of 0.31 to 0.35 at 25 to $30^{\circ} \mathrm{C}$ storage and 0.35 to 0.39 at $35^{\circ} \mathrm{C}$. At 18 mo, the 25 and $30^{\circ} \mathrm{C}$ samples had $\mathrm{a}_{\mathrm{w}}$ values of 0.33 to 0.38 . The differences due to time and temperature were significant; RH and bag type made no difference. 


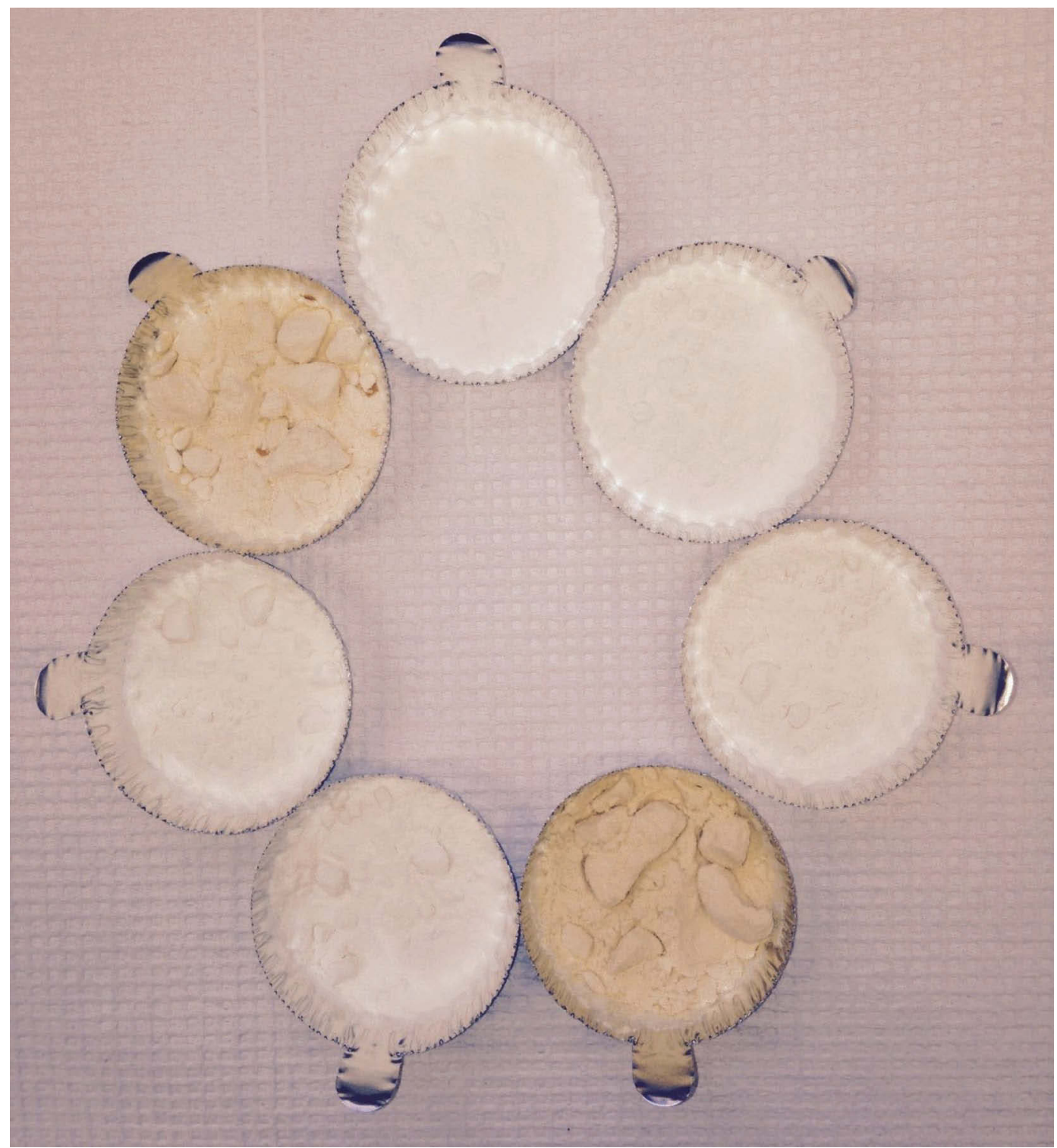

Figure 1. Samples of whey protein concentrate with 34\% protein (WPC34) in standard bags after being stored at various temperature and relative humidity (RH) levels for 12 mo. Clockwise from top: ambient (about $21^{\circ} \mathrm{C}, 45-65 \% \mathrm{RH}$ ), $25^{\circ} \mathrm{C} / 70 \% \mathrm{RH}, 30^{\circ} \mathrm{C} / 70 \% \mathrm{RH}, 35^{\circ} \mathrm{C} / 70 \% \mathrm{RH}$, $25^{\circ} \mathrm{C} / 90 \% \mathrm{RH}, 30^{\circ} \mathrm{C} / 90 \% \mathrm{RH}, 35^{\circ} \mathrm{C} / 90 \% \mathrm{RH}$.

With WPC80 stored at ambient in HP bags, $\mathrm{a}_{\mathrm{w}}$ was 0.22 through the initial $12 \mathrm{mo}$ and 0.25 at 18 mo. The WPC80 samples stored at 25 or $30^{\circ} \mathrm{C}$ in HP bags had $\mathrm{a}_{\mathrm{w}}$ values of 0.27 to 0.30 in the first $12 \mathrm{mo}$ and 0.31 to 0.34 at $18 \mathrm{mo}$; the $35^{\circ} \mathrm{C}$ samples had $\mathrm{a}_{\mathrm{w}}$ values of 0.34 to 0.37 at $12 \mathrm{mo}$. These time and temperature differences were significant $(P<0.05)$. The WPC80 stored in ST bags exhibited significantly higher $\mathrm{a}_{\mathrm{w}}$ values: 0.33 to 0.39 for samples stored at 25 or $30^{\circ} \mathrm{C}$ for $12 \mathrm{mo}$ and 0.37 to 0.44 at 18 mo. The WPC80 stored in ST bags at $35^{\circ} \mathrm{C}$ had $\mathrm{a}_{\mathrm{w}}$ values of 0.46 to 0.47 after $12 \mathrm{mo}$. The time and temperature differences were significant $(P<$
0.05), as was bag type. The lysine results indicated that proteolysis was occurring over time, so bound water was presumably being freed as the proteins were breaking down. Increasing $\mathrm{a}_{\mathrm{w}}$ in dried dairy products usually results in higher $b^{*}$ values because Maillard reactions and nonenzymatic browning are promoted (Stapelfeldt et al., 1997). Maillard products are a noted source of quality loss in whey powders, and Sithole et al. (2005) reported a relationship between storage time and Maillard reactions in their study of sweet whey powder shelf life. In no sample did we detect $a_{w}$ high enough to be conducive for microbial growth. 


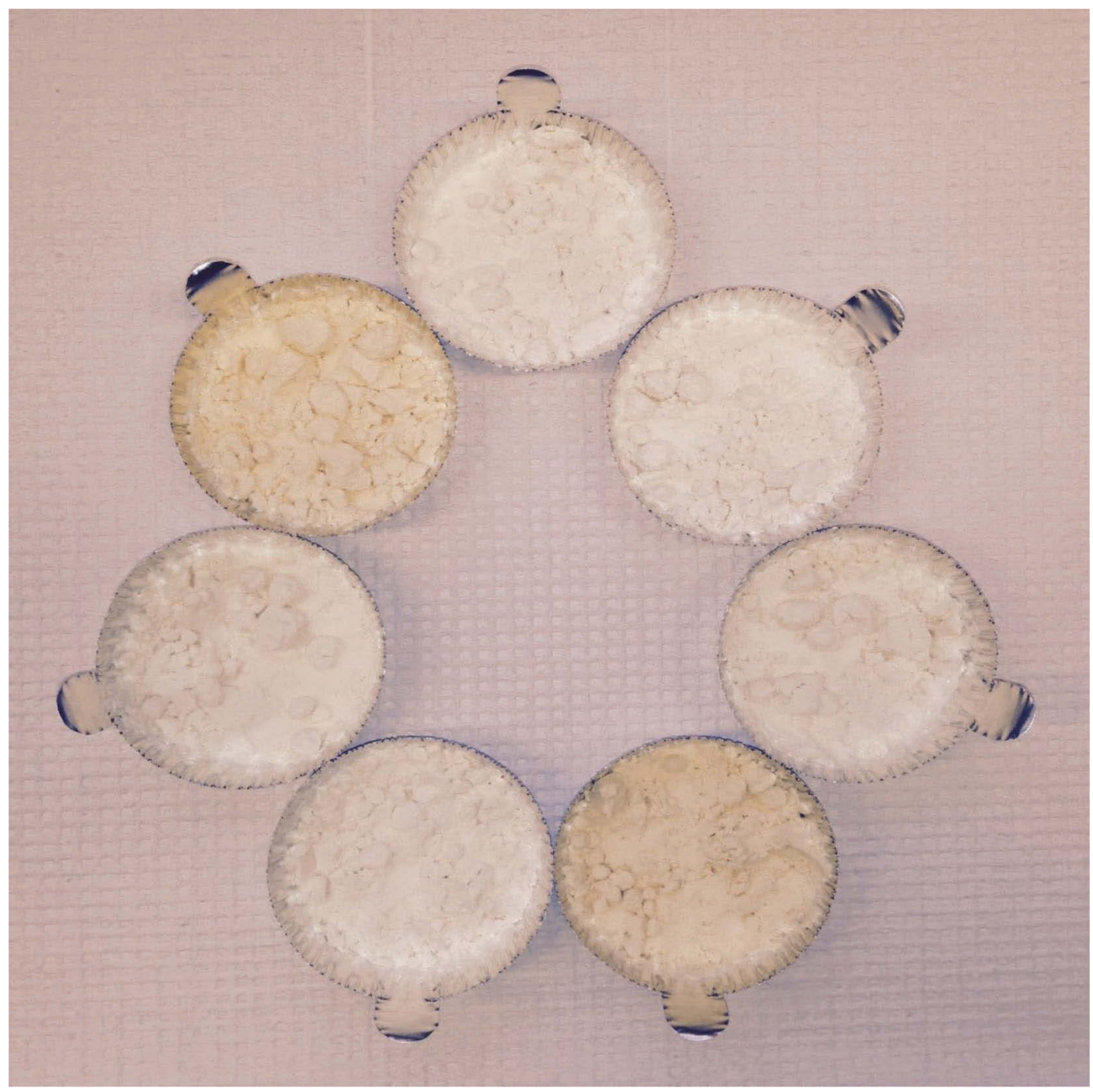

Figure 2. Samples of whey protein concentrate with $80 \%$ protein (WPC 80 ) in standard bags after being stored at various temperature and relative humidity ( $\mathrm{RH}$ ) levels for 12 mo. Clockwise from top: ambient (about $21^{\circ} \mathrm{C}, 45-65 \% \mathrm{RH}$ ), $25^{\circ} \mathrm{C} / 70 \% \mathrm{RH}, 30^{\circ} \mathrm{C} / 70 \% \mathrm{RH}, 35^{\circ} \mathrm{C} / 70 \% \mathrm{RH}$, $25^{\circ} \mathrm{C} / 90 \% \mathrm{RH}, 30^{\circ} \mathrm{C} / 90 \% \mathrm{RH}$, and $35^{\circ} \mathrm{C} / 90 \% \mathrm{RH}$.

\section{Volatile Compounds}

Oxidation in dairy products, especially of fatty acids, leads to formation of aldehydes, methyl ketones, alcohols, and furans, which results in quality loss (Carunchia Whetstine et al., 2005; Javidipour and Qian, 2008; Mortenson et al., 2008). Aldehydes containing 6 to 9 carbon atoms were found, some not until 6 or 12 mo (Table 1). Hexanal was the volatile with the highest concentration, a result also found by Coppola et al. (2014), who attributed its presence to oxidation of oleic and linoleic acids. The level of hexanal was higher in the WPC80, which contained more than twice the amount of fat as the WPC34. The methyl ketones detected were 2-butanone, 3-methyl-2-butanone, 2-heptanone, and 2-nonanone, but all were found in concentrations $<100 \mu \mathrm{g} / \mathrm{kg}$. 2-Methylhexanol was observed almost exclusively in the WPC34, also at $<100$ $\mu \mathrm{g} / \mathrm{kg}$. 1-Butanol, tetrahydrofuran, and 3-methylheptyl acetate were detected at low levels in 4 of the samples.

Some volatiles studied were breakdown products that increased in concentration with time, and others disappeared by 6 mo and apparently degraded while no longer being formed. Compounds that were not detected beyond 3 mo included 2-butanone, 3-methyl2-butanone, and 1-pentanol. All of the compounds detected were previously identified in WPC (Lee et al., 1996; Tunick et al., 2013; Coppola et al., 2014). Increases in the formation of many volatile compounds in WPC have been correlated with increases in $\mathrm{a}_{\mathrm{w}}$ (Lee at al., 1996). Trichloromethane was detected in many samples, with WPC80 containing significantly more 
(up to $810 \mu \mathrm{g} / \mathrm{kg}$ ) than WPC34 (up to $205 \mu \mathrm{g} / \mathrm{kg}$ ). The amounts decreased with time. Bromodichloromethane at $<40 \mu \mathrm{g} / \mathrm{kg}$ was also detected in WPC80 at 0 and 3 mo. Trichloromethane and other halogenated compounds have previously been found in WPC and may have originated from chlorinated tap water used in

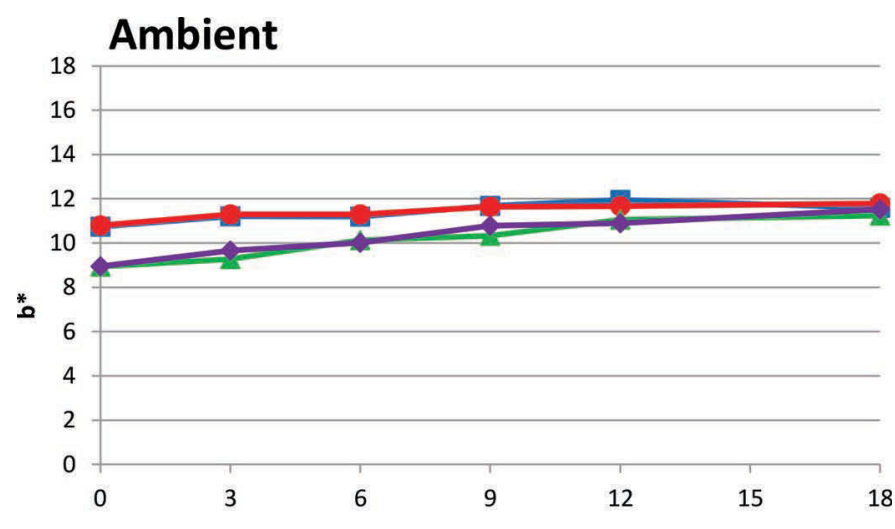

$30^{\circ} \mathrm{C} / 70 \% \mathrm{RH}$

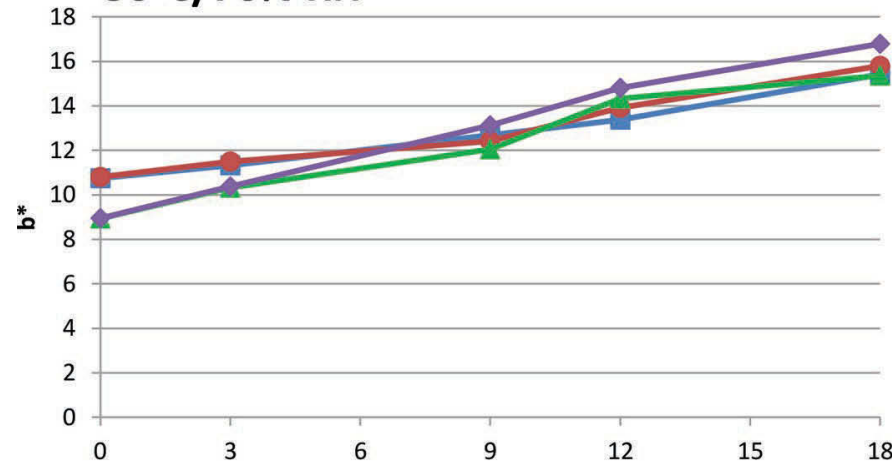

$35^{\circ} \mathrm{C} / 70 \% \mathrm{RH}$

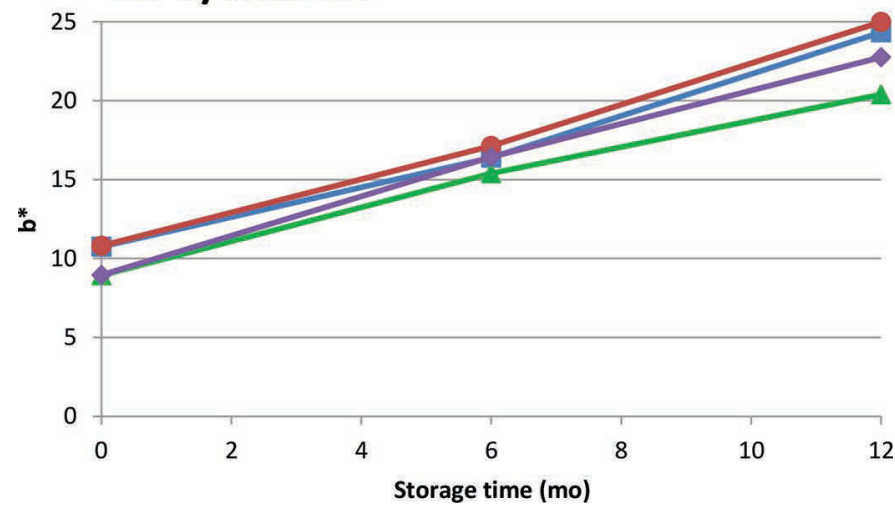

Figure 3. Color changes in $b^{*}$ (yellowness) during storage of whey protein concentrate with $34 \mathrm{~g}$ of protein/100 $\mathrm{g}$ (WPC34) or $80 \mathrm{~g}$ of protein/100 g (WPC80) in high-performance (HP) and standard (ST) bags at ambient temperature and relative humidity $(\mathrm{RH})$, and at $70 \%$ relative humidity $(\mathrm{RH})$ and 30 and $35^{\circ} \mathrm{C}$. Blue/squares $=\mathrm{WPC} 34, \mathrm{HP}$; red $/$ circles $=$ WPC34, ST; green/triangles $=$ WPC80, HP; purple diamonds $=$ WPC80, ST . Error bars are not shown because standard deviations were all $<0.50$. Color version available online. processing or from a reaction of residual hypochlorite sanitizer with protein or lactose (Lee et al., 1996; Ha et al., 2002). Dimethyl disulfide, a breakdown product of the sulfur-containing AA cysteine and methionine, was at higher levels in WPC80 and increased with temperature and storage time, starting at $<10 \mu \mathrm{g} / \mathrm{kg}$ within the first $3 \mathrm{mo}$ and reaching 800 to $1,040 \mu \mathrm{g} / \mathrm{kg}$ after 12 mo. Limonene, a terpene found in milk from cows on pasture, was also observed in the WPC80, but at a concentration $<75 \mu \mathrm{g} / \mathrm{kg}$. One other compound seen in some samples at low concentrations after 6 mo was 1-decyne, which has been found in milk (Coppa et al., 2011; Yue et al., 2015) and may originate from oxidation of sterculic acid (Fan et al., 1983), a cyclopropene fatty acid that has also been identified in milk (Griinari et al., 1998). Limonene, 1-decyne, and the other compounds found at low levels probably play no role in WPC quality, however.

\section{Fatty Acids}

The fatty acid profiles were within reported ranges for commercial US milk (Palmquist et al., 1993). The percentages of fatty acids did not change significantly from the beginning of the study to the end.

\section{Powder Flow}

Bulk density is the solid weight per volume unit of the powder, including air entrapped within particles and void volume between particles. The maximum bulk density of the WPC34 was between 710 and $840 \mathrm{~kg} /$ $\mathrm{m}^{3}$. The values for WPC 80,450 to $510 \mathrm{~kg} / \mathrm{m}^{3}$, were significantly lower due to interstitial and occluded air, meaning that larger outlet diameters would be required for optimal flow of the WPC80. The results agree with those of Pordesimo et al. (2009), who found that the bulk density of WPC34 was $69 \%$ greater than that of WPC80. Temperature, RH, and bag type did not affect the results. The values did not change appreciably over $18 \mathrm{mo}$, a result also found by Wright et al. (2009).

Rat-holing is the primary flow obstruction in a coreflow vessel. A rathole forms when the powder above the outlet flows out and the material at the walls does not. The values for critical rathole density, the minimum density required to prevent the formation of a stable rathole, were not significantly different from the maximum bulk density values. The critical rathole diameter (the minimum outlet diameter needed to ensure flow) of the WPC80 samples was always between 1.92 and $2.00 \mathrm{~m}$. The values for the WPC34 samples depended on storage temperature: before being removed from the study, the bags in the $35^{\circ} \mathrm{C}$ chambers exhibited significantly higher values than the other bags (Figure 5). 


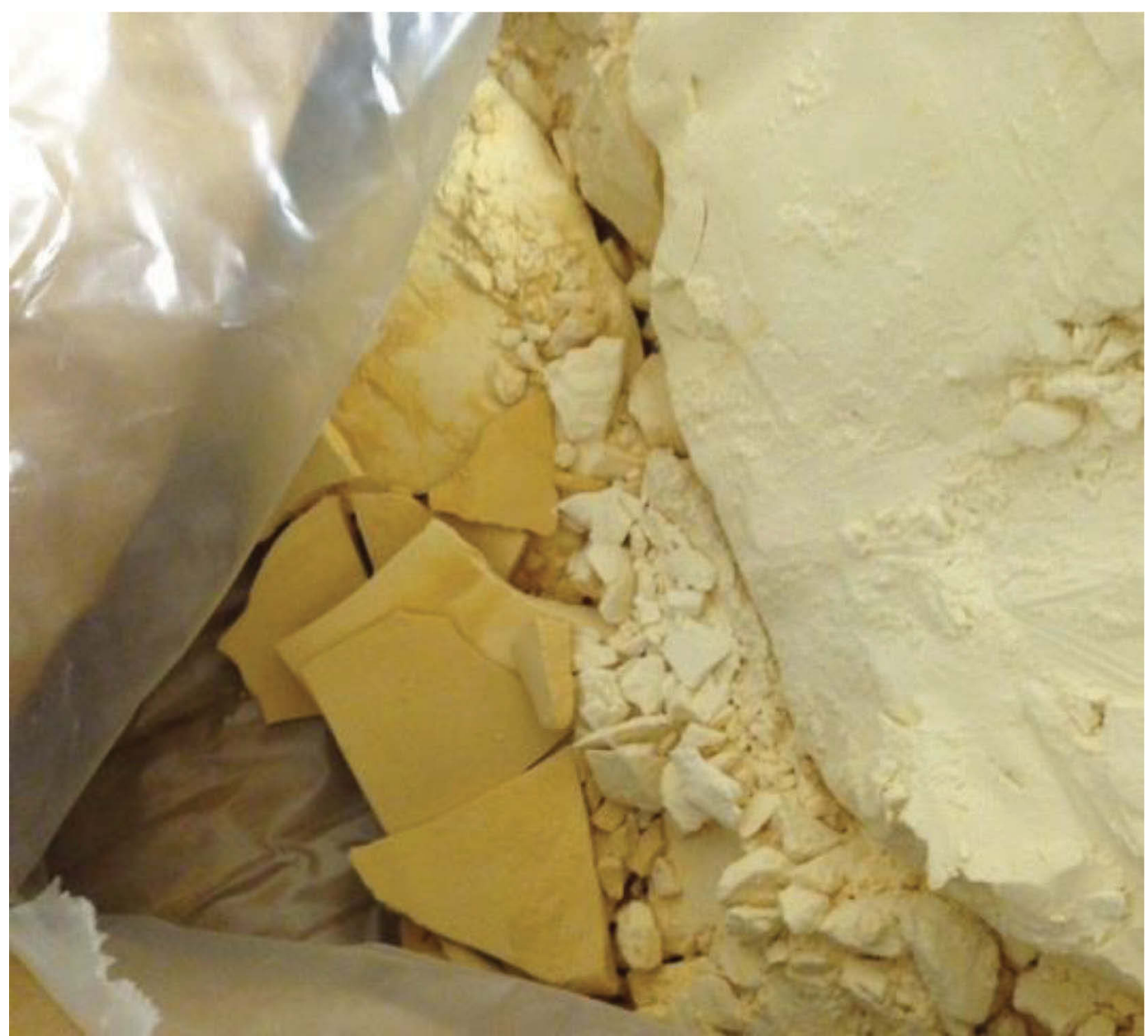

Figure 4. Brown chip formation in whey protein concentrate with $34 \%$ protein (WPC34) bags stored at $90 \%$ relative humidity.

The WPC34 stored in ST bags also displayed higher critical rathole diameters at 18 mo than the bags stored at lower temperatures.

Arching is the primary flow obstruction in a massflow vessel, where the powder above the outlet forms a stable arch and prevents flow. The critical arching density, the minimum density required to prevent the formation of a stable arch, was 516 to $569 \mathrm{~kg} / \mathrm{m}^{3}$ for the WPC34 and 321 to $379 \mathrm{~kg} / \mathrm{m}^{3}$ for the WPC80, a significant difference $(P<0.05)$. The critical arching

Table 1. Volatile compounds $(\mu \mathrm{g} / \mathrm{kg}$ ) in whey protein concentrates with $34 \%$ (WPC34) and $80 \%$ (WPC 80 ) protein during 18 mo of storage under ambient conditions ${ }^{1}$

\begin{tabular}{|c|c|c|c|c|c|c|c|c|c|c|c|}
\hline $\mathrm{RT}^{2}$ & Compound & \multicolumn{5}{|c|}{ WPC34 } & \multicolumn{5}{|c|}{ WPC80 } \\
\hline 5.28 & Hexanal & 18 & 42 & 61 & 109 & 171 & 79 & 125 & 252 & 388 & 752 \\
\hline 7.39 & Heptanal & ND & ND & 12 & $-^{4}$ & 28 & 14 & 16 & 33 & 256 & 84 \\
\hline 9.34 & Octanal & ND & ND & ND & 12 & 9 & ND & ND & ND & 15 & 23 \\
\hline 11.10 & Nonanal & 5 & 6 & 5 & 87 & 21 & 10 & 16 & 5 & 78 & 47 \\
\hline
\end{tabular}

${ }^{1}$ Averages of high-performance bags $(n=3)$ and standard bags $(n=3)$, which were not significantly different.

${ }^{2}$ Retention time (min).

${ }^{3}$ Not detected.

${ }^{4}$ Obscured by siloxane peak. 
diameter (the minimum outlet diameter required for reliable gravity discharge) ranged from 2 to $12 \mathrm{~cm}$ in the WPC34 samples and 12 to $19 \mathrm{~cm}$ in the WPC80 samples. The values did not vary by storage time or conditions.

\section{Powder Caking}

Some clumping and caking were observed in all samples after 9 to 12 mo of storage, and was pronounced in the powders stored at $35^{\circ} \mathrm{C}$ (Figures 1 and 2). Water
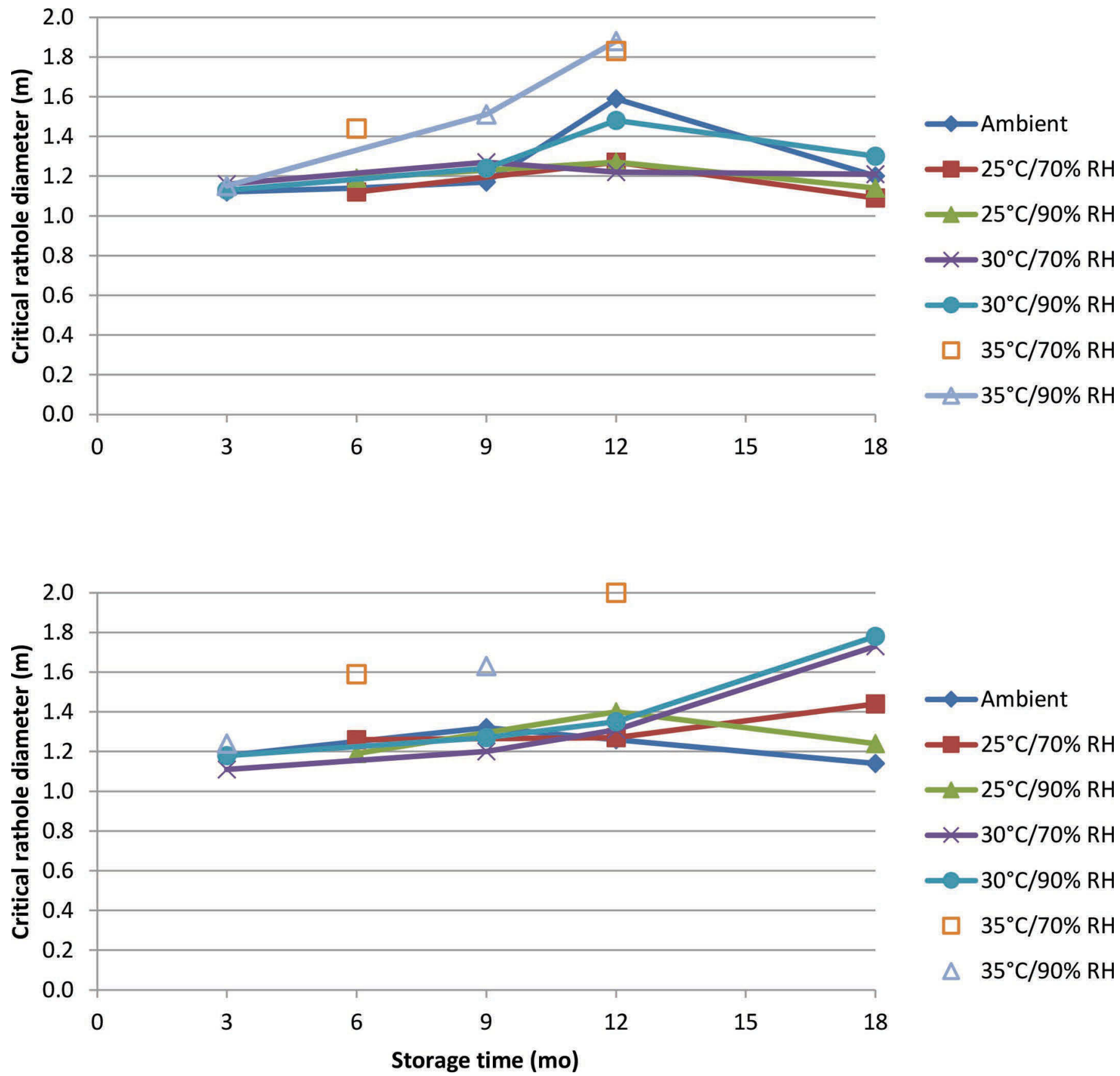

Figure 5. Critical rathole diameter in whey protein concentrate with $34 \%$ protein (WPC34) stored in high-performance bags (top) and standard bags (bottom) under ambient conditions and at 25,30, and $35^{\circ} \mathrm{C}$ and at 70 and $90 \%$ relative humidity (RH). Error bars are not shown because standard deviations were all $<0.10$. Color version available online. 
adsorption by lactose and protein contribute to the well-known hygroscopicity of whey powders (Early, 1998), which leads to caking of the product. During the first 12 mo of the study, the powder caking values ranged from 1.3 to $2.3 \mathrm{~mm}$ for WPC34 and 3.2 to 4.0 $\mathrm{mm}$ for WPC80, indicating that the latter was significantly more compactable. Dairy powder properties are affected by fat, which partially melts at elevated temperatures, and lactose, which may crystallize or partially dissolve in the presence of moisture, forming bridges between the particles (Fitzpatrick et al., 2007). Dairy powders become more cohesive when the fat content is increased, due to stickiness (Nijdam and Langrish, 2006); the WPC80 contained $6.2 \%$ fat compared with the $2.8 \%$ fat in the WPC34. Dairy powders are also more cohesive and display more caking when the particle size is smaller (Rennie et al., 1999). The mean and median volume-weighted particle sizes of WPC34 are around 2,200 and $1,800 \mu \mathrm{m}$, respectively, whereas the corresponding values for WPC80 are both around 3,300 $\mu \mathrm{m}$ (Pordesimo et al., 2009).

After 18 mo of storage, some of the powder caking values were within the original ranges, but a significant increase in ability to compact (values of 12.3-15.4 $\mathrm{mm}$ ) was observed in the WPC34 stored in ST bags at $30^{\circ} \mathrm{C} / 70 \% \mathrm{RH}$, and in the WPC34 and WPC 80 samples stored in $\mathrm{HP}$ bags at $25^{\circ} \mathrm{C} / 90 \% \mathrm{RH}$ and $30^{\circ} \mathrm{C} / 70 \% \mathrm{RH}$. The other WPC34 samples stored in ST bags, along with several other samples, exhibited coefficients of variation $>76 \%$. The large coefficients resulted from some of the 5 replicates having high values and others having low ones, which points to the lack of homogeneity that developed in some of the samples. Caking may increase during storage due to prolonged contact between powder particles, which would allow for greater interaction of attractive forces (Teunou and Fitzpatrick, 2000). In contrast, none of the WPC80 samples stored in ST bags and none of the samples stored at $30^{\circ} \mathrm{C}$ and 90\% RH exhibited high values at 18 mo. This contradiction underlines some of the well-known difficulties in explaining caking behavior of powders. Components such as lactose become more plastic and cohesive above room temperature, but moisture loss at elevated temperatures will decrease cohesiveness (Fitzpatrick et al., 2007). These 2 effects were apparently balanced in the samples that did not display an increase in caking with storage.

\section{Powder Compressibility}

The WPC34 required significantly more force to compress than the WPC80. Peak forces of the ambient WPC34 samples ranged from 41.68 to $54.24 \mathrm{~kg}$ throughout storage, and those of the other WPC34 samples were 39.04 to $52.52 \mathrm{~kg}$ during the $18 \mathrm{mo}$. Peak forces of the ambient WPC80 samples ranged from 27.52 to $32.35 \mathrm{~kg}$, compared with 23.01 to $33.13 \mathrm{~kg}$ for the other WPC80 samples. The air within and between the WPC80 particles, as noted with the powder flow tests, allowed the material to be compressed with less force.

The force at $45 \mathrm{~s}$ was compared with peak force to determine loss of powder strength. Throughout ambient storage, WPC34 retained 89 to $93 \%$ of its strength (7-11\% relaxation) and the more compressible WPC 80 retained 86 to $89 \%$. After 18 mo, the samples held at elevated temperature and $\mathrm{RH}$ had insignificantly lower values: 86 to $91 \%$ for WPC34 and 85 to $90 \%$ for WPC80.

\section{Solubility}

Under almost all storage conditions, the solubility of the WPC34 (74-97\%) was significantly greater than that of the WPC80 (63-88\%), which contains higher levels of protein. The solubility of the WPC34 was 81 to $88 \%$ at $18 \mathrm{mo}$, which was significantly less than the initial values of 90 to $92 \%$. The WPC 80 solubility was 63 to $76 \%$ during the first $3 \mathrm{mo}$ and did not significantly change after that. A storage study at $37^{\circ} \mathrm{C}$ of WPC containing $35 \mathrm{~g}$ of protein $/ 100 \mathrm{~g}$ showed that solubility decreased by $14 \%$ in $42 \mathrm{~d}$ (Li-Chan, 1983). The WPC34, with its high lactose content, is expected to undergo Maillard reactions to a greater extent than WPC80, and the conditions that favor these reactions are also conducive to cross-linking between AA such as disulfide bond formation, which would reduce solubility (Anema et al., 2006).

\section{Microbiology}

Microbial contamination and presence of spores were not issues in this study because of the low $\mathrm{a}_{\mathrm{w}}$. The maximum values observed for various bacteria and yeast/ mold were 3.78 and $3.82 \log _{10} \mathrm{cfu} / \mathrm{g}$, respectively. No coliforms were detected in any sample. A more detailed microbiological study has been conducted by Ukuku et al. (2015).

\section{Effects of Bag Type and Suggestions for Industry}

The WPC in the ST and HP bags performed similarly during the study. Browning is known to occur in dry dairy products stored at elevated temperatures, and clumping takes place when lactose absorbs moisture (US Dairy Export Council, 2014). As previously mentioned, brown chips and chunks formed in both the ST and HP bags containing WPC34. All of the bags in the study 
remained sealed until their analysis times, when they were opened, sampled, and discarded, so the outside atmosphere did not come in contact with the material during storage except by penetration through the liner. Dairy processors may consider bags with thicker plastic liners than usual because shipments could be handled improperly during loading and unloading, which might result in tearing of normal bags. However, thicker bag liners were not shown to enhance shelf life; instead, storage of WPC34 below $35^{\circ} \mathrm{C}$ and $90 \% \mathrm{RH}$ is of primary importance. Alternatively, modified-atmosphere packaging may help prevent color and clumping defects from developing. This is an area that has not been explored with WPC.

Deterioration of quality characteristics of whey powder, such as lysine loss (Li-Chan, 1983), browning (Sithole et al., 2005), and lipid oxidation (Javidipour and Qian, 2008; Wright et al., 2009), have been shown to occur during storage. Moreover, powder flow has been observed to be adversely affected at elevated temperatures (Fitzpatrick et al., 2007). The results of the present study are consistent with these prior investigations. Other research has identified changes in flavor, gelation, and surface properties in whey protein (Morr and Ha, 1993), which this study did not address, but the data reported here indicate that changes in these characteristics would likely occur during storage at elevated temperatures. Our results showed that RH was less of a factor than temperature, and it is reasonable to assume that this conclusion would apply to flavor and functional properties. Also, this study dealt with whey from Mozzarella manufacture, which may have different fatty acid and volatile compound profiles than the whey of Cheddar or other varieties. These areas will also have to be investigated.

\section{CONCLUSIONS}

In this case study, WPC 34 stored at $35^{\circ} \mathrm{C}$ became unacceptable after 9 to 12 mo because of clumping and yellowing, and all samples became yellower by $18 \mathrm{mo}$ under all storage conditions. The void spaces between WPC80 particles adversely affected its flow properties, but these values did not change with storage. The solubility of WPC34 decreased with storage but remained higher than that of WPC80. The HP bags did not outperform the ST bags. Relative humidity did not appreciably affect any of the results, although some hardening and browning was noted in the bags stored at high temperature and $\mathrm{RH}$ for 12 mo. Our results indicate that sealed bags of WPC34 may be stored up to $9 \mathrm{mo}$ at $35^{\circ} \mathrm{C}$ and WPC 80 may be stored up to a year at $30^{\circ} \mathrm{C}$ and maintain physical properties.

\section{ACKNOWLEDGMENTS}

The authors thank the following USDA, Wyndmoor employees for their help: Eric Tilman for sampling the bags and performing many of the physical and chemical tests; Edward Wickham for the solubility analyses; Lee Chau for microbiological assays; and Neil Goldberg, Mario Arnone, and Ken Todd for designing, obtaining, and building the environmental chambers. This work was performed under cooperative agreement 58-1935086-04T with the Dairy Research Institute (Rosemont, IL).

\section{REFERENCES}

Anema, S. G., D. N. Pinder, R. J. Hunter, and Y. Hemar. 2006. Effects of storage temperature on the solubility of milk protein concentrate (MPC85). Food Hydrocoll. 20:386-393.

Buera, M. P., J. Chirife, and S. L. Resnik. 1990. Nonenzymatic nonoxidative browning in hydrolyzed shelf-stable concentrated cheese whey. J. Food Sci. 55:697-700.

Carunchia Whetstine, M. E., A. E. Croissant, and M. A. Drake. 2005. Characterization of dried whey protein concentrate and isolate flavor. J. Dairy Sci. 88:3826-3839.

Coppa, M., B. Martin, P. Pradel, B. Leotta, A. Priolo, and V. Vasta. 2011. Effect of a hay-based diet or different upland grazing systems on milk volatile compounds. J. Agric. Food Chem. 59:4947-4954.

Coppola, L. E., M. S. Molitor, S. A. Rankin, and J. A. Lucey. 2014. Comparison of milk-derived whey protein concentrates containing various levels of casein. Int. J. Dairy Technol. 67:467-473.

Crowley, S. V., I. Gazi, A. L. Kelly, T. Huppertz, and J. A. O'Mahony. 2014. Influence of protein concentration on the physical characteristics and flow properties of milk protein concentrate powders. J. Food Eng. 135:31-38.

Dattatreya, A., W. Lee, and S. A. Rankin. 2010. Presence of galactose and glucose promotes browning of sweet whey powder. J. Dairy Sci. 93:2354-2357.

Delaney, R. A. M. 1976. Composition, properties and uses of whey protein concentrates. Int. J. Dairy Technol. 29:91-101.

Early, R. 1998. Page 283 in Technology of Dairy Products. 2nd ed. Thomson Sci., Philadelphia, PA.

Fan, L. L., J. Y. Tang, and A. Wohlman. 1983. Investigation of 1-decyne formation in cottonseed oil fried foods. J. Am. Oil Chem. Soc. 60:1115-1119.

Fitzpatrick, J. J., K. Barry, P. S. M. Cerqueira, T. Iqbal, J. O’Neill, and Y. H. Roos. 2007. Effect of composition and storage conditions on the flowability of dairy powders. Int. Dairy J. 17:383-392.

Griinari, J. M., D. A. Dwyer, M. A. McGuire, D. E. Bauman, D. L. Palmquist, and K. V. V. Nurmela. 1998. Trans-octadecenoic acids and milk fat depression in lactating dairy cows. J. Dairy Sci. 81:1251-1261.

Grimsley, G. R., and C. N. Pace. 2004. Spectrophotometric determination of protein concentration. Curr. Protocols Prot. Sci. 3.1.13.1.9.

Ha, E. Y. W., S. J. Lee, E. J. Jung, Y. B. Lee, and C. V. Morr. 2002. Dynamic headspace analysis of volatile constituents of Swiss cheese whey protein concentrate. J. Food Sci. Nutr. 7:299-304.

Hitchins, A. D., P. Feng, W. D. Watkins, S. R. Rippey, and L. A. Chandler. 1992. FDA Bacteriological Analytical Manual. Food and Drug Administration, Washington, DC.

Ichihara, K., A. Shibahara, K. Yamamoto, and T. Nakayama. 1996. An improved method for rapid analysis of the fatty acids of glycerolipids. Lipids 31:535-539.

Javidipour, I., and M. C. Qian. 2008. Volatile component change in whey protein concentrate during storage investigated by headspace solid-phase microextraction gas chromatography. Dairy Sci. Technol. 88:95-104. 
Labuza, T. P., and M. Saltmarch. 1982. Kinetics of browning and protein quality loss in whey powders during steady state and nonsteady state storage conditions. J. Food Sci. 47:92-96.

Lagrange, V., D. Whitsett, and C. Burris. 2015. Global market for dairy proteins. J. Food Sci. 80(Suppl. 1):A16-A22.

Lee, Y. B., I. Laye, Y. D. Kim, and C. V. Morr. 1996. Formation of volatile compounds in whey protein concentrate during elevated temperature storage as a function of water activity. Int. Dairy J. 6:485-496.

Li-Chan, E. 1983. Properties and molecular interactions of whey protein concentrates upon storage. J. Dairy Sci. 66:1843-1853.

Listiohadi, Y. D., J. A. Hourigan, R. W. Sleigh, and R. J. Steele. 2005. An exploration of the caking of lactose in whey and skim milk powders. Aust. J. Dairy Technol. 60:207-213.

Mahmoudi, N., S. Mehalebi, T. Nicolai, D. Durand, and A. Riaublanc. 2007. Light-scattering study of the structure of aggregates and gels formed by heat-denatured whey protein isolate and $\beta$-lactoglobulin at neutral pH. J. Agric. Food Chem. 55:3104-3111.

Morr, C. V., and E. Y. W. Ha. 1993. Whey protein concentrates and isolates: Processing and functional properties. Crit. Rev. Food Sci. Nutr. 33:431-476.

Mortenson, M. A., Z. M. Vickers, and G. A. Reineccius. 2008. Flavor of whey protein concentrates and isolates. Int. Dairy J. 18:649-657.

Nijdam, J. J., and T. A. G. Langrish. 2006. The effect of surface composition on the functional properties of milk powders. J. Food Eng. 77:919-925.

Palmquist, D. L., A. D. Beaulieu, and D. M. Barbano. 1993. Feed and animal factors influencing milk fat composition. J. Dairy Sci. $76: 1753-1771$.

Pordesimo, L. O., C. I. Onwulata, and C. W. P. Carvalho. 2009. Food powder delivery through a feeder system: effect of physicochemical properties. Int. J. Food Prop. 12:556-570.

Qi, P. X., D. Ren, Y. Xiao, and P. M. Tomasula. 2015. Effect of homogenization and pasteurization on the structure and stability of whey protein in milk. J. Dairy Sci. 98:2884-2897.

Rennie, P. R., X. D. Chen, C. Hargreaves, and A. R. Mackereth. 1999 A study of the cohesion of dairy powders. J. Food Eng. 39:277-284.

Richardson, R. K. 2001. Determination of fat in dairy products using pressurized solvent extraction. J. AOAC Int. 84:1522-1533.

Sithole, R., M. R. McDaniel, and L. M. Goddik. 2005. Rate of Maillard browning in sweet whey powder. J. Dairy Sci. 88:1636-1645.
Stapelfeldt, H., B. R. Nielsen, and L. H. Skibsted. 1997. Effect of heat treatment, water activity and storage temperature on the oxidative stability of whole milk powder. Int. Dairy J. 7:331-339.

Teunou, E., and J. J. Fitzpatrick. 2000. Effect of storage time and consolidation on food powder flowability. J. Food Eng. 43:97-101.

Tunick, M. H., S. K. Iandola, and D. L. Van Hekken. 2013. Comparison of SPME methods for determining volatile compounds in milk, cheese, and whey powder. Foods 2:534-543.

Ukuku, D. O., C. Onwulata, S. Mukhopadhyay, L. Chau, A. E. Thomas-Gahring, and M. H. Tunick. 2015. Effect of humidity and temperature on microbial populations of WPC-34 and WPC-80 whey protein during long-term storage. J. Food Process. Preserv. In press.

Ukuku, D. O., C. Onwulata, A. Thomas, S. Mukhopadhyay, and M. Tunick. 2014. Behavior of native microbial populations of WPC34 and WPC-80 whey protein stored at different temperatures. J. Food Process. Technol. 5:304. http://dx.doi.org/10.4172/21577110.1000304.

US Dairy Export Council. 2014. Optimizing the quality and shelf life of dairy ingredients. Accessed Aug. 7, 2015. http://www.dairyglobalnutrition.org/SafeQuality/content. cfm?ItemNumber $=88701 \#$ Color $/$ Browning.

USDA. 2006. Milk price support program purchase, Announcement Dairy 6. Accessed Aug. 7, 2015. https://www.fsa.usda.gov/ Internet/FSA_File/dairy6.pdf.

Webb, P., B. P. Rogers, I. Rosenberg, N. Schlossman, C. Wanke, J. Bagriansky, K. Sadler, Q. Johnson, J. Tilahun, A. R. Masterson, and A. Narayan. 2011. Pages $245-250$ in Improving the Nutritional Quality of U.S. Food Aid: Recommendations for Changes to Products and Programs. Tufts University, Boston, MA.

Wright, B. J., S. E. Zevchak, J. M. Wright, and M. A. Drake. 2009 The impact of agglomeration and storage on flavor and flavor stability of whey protein concentrate $80 \%$ and whey protein isolate. J. Food Sci. 74:S17-S29.

Yue, J., Y. Zheng, Z. Liu, Y. Deng, Y. Jing, Y. Luo, W. Yu, and Y. Zhao. 2015. Characterization of volatile compounds in microfiltered pasteurized milk using solid-phase microextraction and GC $\times$ GC-TOFMS. Int. J. Food Prop. 18:2193-2212. 